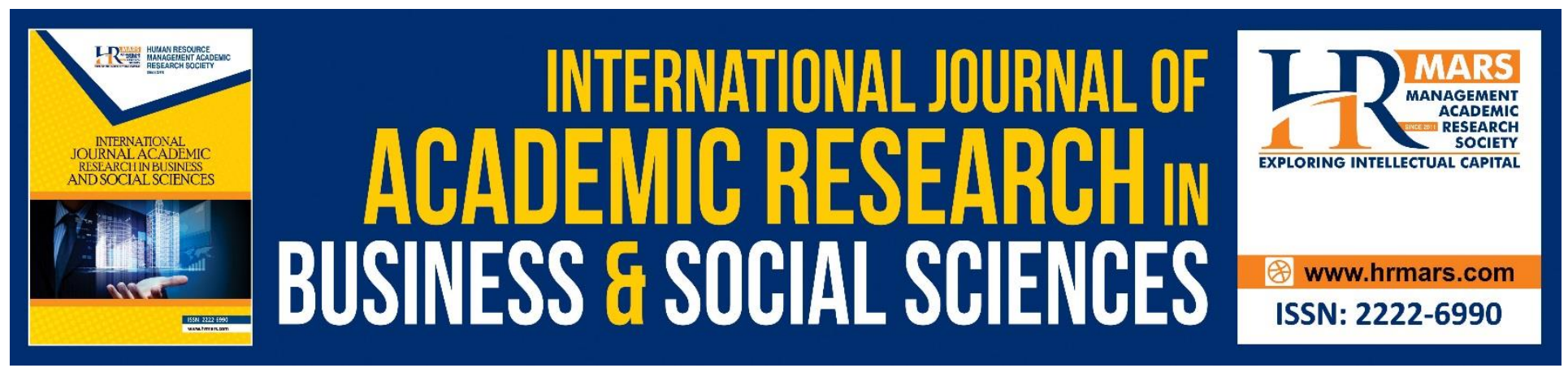

\title{
Exploring Digital Platforms, Cultural Tourism and Online Learning of Museums Worldwide
}

Muhamad Amirul Hafiz bin Zulkifli, Mohd Syuhaidi Abu Bakar, Khairul Nishak binti Harun, Mohamad Syafiq Bin Mat Shuki

To Link this Article: http://dx.doi.org/10.6007/IJARBSS/v10-i6/7338

DOI:10.6007/IJARBSS/v10-i6/7338

Received: 02 March 2020, Revised: 22 April 2020, Accepted: 29 May 2020

Published Online: 02 June 2020

In-Text Citation: (Zulkifli et al., 2020)

To Cite this Article: Zulkifli, M. A. H. bin, Bakar, M. S. A., Harun, K. N. binti, \& Shuki, M. S. B. M. (2020). Exploring Digital Platforms, Cultural Tourism and Online Learning of Museums Worldwide. International Journal of Academic Research in Business and Social Sciences, 10(6), 633-642.

Copyright: (C) 2020 The Author(s)

Published by Human Resource Management Academic Research Society (www.hrmars.com)

This article is published under the Creative Commons Attribution (CC BY 4.0) license. Anyone may reproduce, distribute, translate and create derivative works of this article (for both commercial and non-commercial purposes), subject to full attribution to the original publication and authors. The full terms of this license may be seen

at: http://creativecommons.org/licences/by/4.0/legalcode

Vol. 10, No. 6, 2020, Pg. 633 - 642

http://hrmars.com/index.php/pages/detail/IJARBSS

JOURNAL HOMEPAGE

Full Terms \& Conditions of access and use can be found at

http://hrmars.com/index.php/pages/detail/publication-ethics 


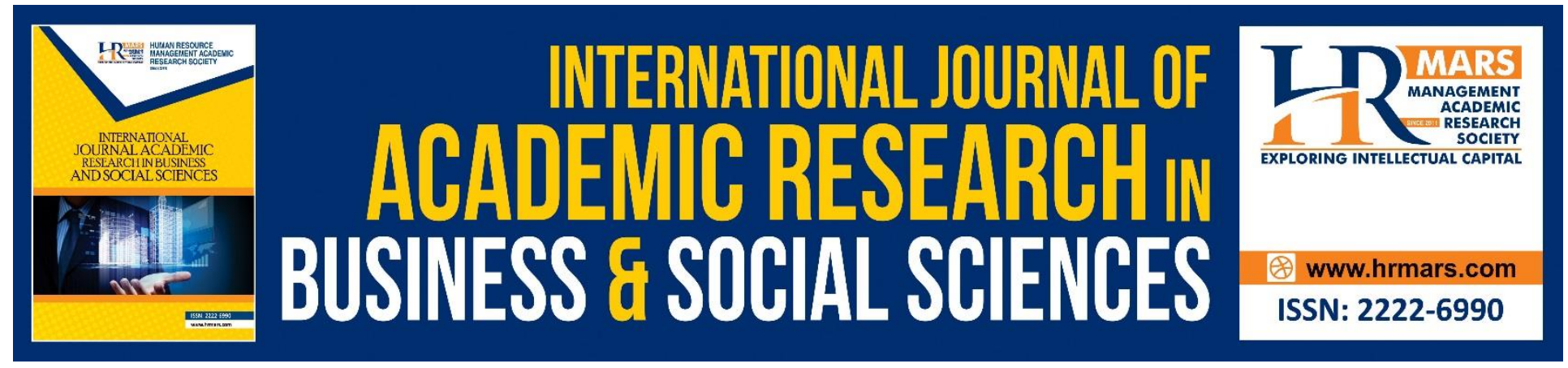

\title{
Exploring Digital Platforms, Cultural Tourism and Online Learning of Museums Worldwide
}

\author{
Muhamad Amirul Hafiz bin Zulkifli \\ Faculty of Film, Theatre and Animation, Universiti Teknologi MARA, Malaysia \\ Email: amirulhafizzulkifli@gmail.com \\ Mohd Syuhaidi Abu Bakar \\ Faculty of Film, Theatre and Animation, Universiti Teknologi MARA, Malaysia \\ Email: syuhaidi@uitm.edu.my \\ Khairul Nishak binti Harun \\ Assistant Director (Museum) \\ International Institute of Islamic Thought and Civilisation (ISTAC), IIUM \\ Email: khairulnishak@iium.edu.my \\ Mohamad Syafiq Bin Mat Shuki \\ Faculty of Film, Theatre and Animation, Universiti Teknologi MARA, Malaysia \\ Email: syafiqshuki@gmail.com
}

\begin{abstract}
In recent years, museum institutions has changed its dominance to become increasingly focused on visitor attractions. Museum institutions all over the world have created a paradigm shift to remain relevant in the eyes of the public (visitors). Museums displacement is strengthened as a digital platform, cultural tourism and online learning for the global community. This study presents a framework for a museum that is relevant to the community through three (3) aspects: digital platforms, cultural tourism and online learning. This study focused on these three aspects that reflect the changes in the perspectives of professional museums rather than serving as a traditional museum (focused on custodial care) to more current (focused to educate and entertain the community). This study confirms that a museum is now connected with three aspects that associates with digital aspects, aspects of online learning and aspects of cultural tourism towards the community and tourists.
\end{abstract}

Keywords: Digital Museums, Cultural Tourism, Online Learning. 


\section{Introduction}

In the beginning, a museum acts as an institution dealing with the substance of art history. However, the status of a museum has changed in terms of its importance for a country, particularly in the tourism sector and for non-formal education institutions (a knowledge center). Once upon a time, the existence of museums in Europe was a manifestation of society and defined the status of the European community (Sternau, 1999). In general, a museum is a public entity of a permanent nonprofit organization for long-term sustainability for a community and a country (Birtley, 2002). A museum is referred to as an institution that builds a broad mind capable of creating awareness of the culture of the country through exhibition activities. Museums can be a role model for the educational system.

Besides that, a museum institution is also set up as a place of cultural tourism for tourists to visit. Cultural tourism aims to highlight the cultural adaptation within the community of their place. Cultural tourism leads to variations of museums such as museum of history, museum of ethnology, museum of culture, museum of science and technology and many more (Yusof, 2013). Cultural tourism was shown through an exhibition by displaying the culture of the community. Communitybased cultures are divided into tangible and non-tangible cultures. The tangible culture describes the human creation that has value and uses it in its community. While, the non-tangible culture describes practices, belief systems, thoughts, and values among the community. In the current millennium, images of the museum changed with the delivery of activities and programs that emphasize the digital aspects for the community. Digital aspects have been seen as a center of knowledge, medium transfer of knowledge as well as attraction of cultural tourism to tourists.

\section{Reviews of Literature and Conceptual Framework}

Previous study stated by Kozinets, Gretzel and Dinhopl (2017) mentioned that visitors to the museum captured selfie photos of themselves during the museum's visit. This aspect of digital image capture is categorized as a desire to take a photo and share it online with other viewers as lively. On the basis of the psychological research, taking pictures of themselves is focused on the relationship with narcissism and the purpose is to contribute to a holistic, conceptual and cultural perspective. The following context has shown that the museum has a connection toward digital, cultural tourism and online learning, as the museum is a place of art, full of history, contributing to education and culture. The connection was illustrated through the visitor's behavior of taking pictures of themselves in the museum. Furthermore, a museum institution has been sustainable and is moving towards the importance of the digital museum 4.0. This is because, through the digital museum 4.0, the museum needs to be concerned about how the museum's data or information are provided to meet the needs of individual visitors. One study also wonders when will a channel for knowledge and reality will be carried out, how research plays a role and how digital applications can be sustainable with the lack of staff in museum management (Hendrajit, 2019). Based on all the above, a museum has emphasized issues related to the use of digital technology. In this process, the development of formats and digital prototypes for research, knowledge, participation, and communication should be evaluated.

At the same time, museums have had to face challenges in managing digital technologies for employees, infrastructure and greater holistic workflows (Sub-projects, 2020). In this regard, some 
museums have been able to move towards digital technology through cooperation with Google Culture, Museum4punkt0 and others. The digital technology of museums remains relevant because as the world is now going through the viral pandemic outbreak, the museum's act smarter by carrying out free audio tours for the 2020 exhibition session, the use of digital technology applications known as 'Shazam for art' app (Brown, 2020). Stow (2011) stated that digitalization was used as a technique or tool to create or to replace the analog objects to digital materials. A museum has created collections through online access. This is to make it easier for researchers or the community (visitors) to access objects via the Internet simply by pressing the click button. Pedersol et al (2016) mentioned that digitalization technology is an aspect that connects with risks. The risk can be defined as an incident that will have a negative impact or consequences towards an organization. Besides, digital technology and online learning are sources of cultural input for products and services that generate innovations in the field of tourism, education, architecture, design, publishing, advertising or gaming. Moreover, it has an impact on the cultural heritage that includes promoting and protecting cultural diversity that contribute to improving the quality of life (Pasikowska-Schnass, 2018). A museum is also seen as a cultural center and a tourist heritage center that defines a means to experience the arts, heritage and activities that represent the history of the past and now.

Cultural heritage tourism is one of the best elements of the tourism industry, and play a role in economic development. It has revealed that a museum is now playing a major role not only in the field of art and history but also in tourism and leisure (Perera, 2013). Because of the current problem, most museums around the world need to close because of the pandemic, but museums continue to provide information on exposure and education to the community through online learning, digital and social media. The Frost Museum, The Wolfsonian- Florida International University and The Florida Jewish Museum lets fans of art and culture to enjoy museums from home with free available information (Corsano, 2020).

The initial draft of the framework through earlier observations as shown in figure 1.0.

Figure 1.0 Digital Platforms, Cultural Tourism and Online Learning of Museums Worldwide

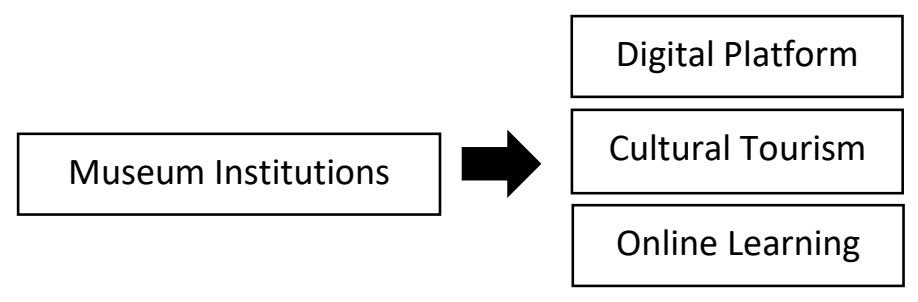

Based on various literatures, a museum connects with three aspects that are associated with digital aspects, online learning aspects and cultural tourism aspects towards the community and tourists.

\section{Method}

According to Awang (2001), data collection is a process related to the design and compilation of data related to certain issues. This study uses a qualitative research design and data were collected using interviews and reviews of literature. Khairul Nishak binti Harun, the Assistant Director (Museum), 
INTERNATIONAL JOURNAL OF ACADEMIC RESEARCH IN BUSINESS AND SOCIAL SCIENCES

Vol. 10, No. 6, June, 2020, E-ISSN: 2222-6990 @ 2020 HRMARS

from the International Institute of Islamic Thought and Civilization (ISTAC), International Islamic University Malaysia (IIUM) was also interviewed. Data were translated verbatim. The findings of the interview and the collection of literature reviews were presented in the results section below.

\section{Results}

\section{Digital Platforms in Museums Worldwide}

The museum was also considered non-functional if there are no visitors (Yusof, 2013). The lack of interest was also influenced by the lack of use of digital media in the process of organizing museum programs and limited promotional items to the community (Yatim, 2005). The museum also experienced a drastic change through The Fourth Industrial Revolution that involves the Internet of Things (IOT). Klaus Schwab who is the founder of the World Economic Forum said, The Fourth Industrial Revolution is characterized by the entry of smart robots' supercomputers, driverless vehicles, gene editing and development of neurotechnology that enable humans to further boost the functioning of the brain (Universiti Malaysia Pahang, 2020). The scenario was slowly beginning to develop and will become a common norm in the future.

Digital technology is important not only for visitors' experience, but also for maintaining and organizing the exhibition. Digital technology built-in with The Fourth Industrial Revolution also brought an effective way of obtaining the information of acquisition, representation, and other stored information. The structure that has lost, damaged, destroyed objects or specimens found by artifacts can be restored thanks to 3D digital reconstructions, such as materials of cultural objects (Münster, Hegel \& Kröber, 2017). The museum experiences digital technology through four (4) aspects with the help of digital technology, interactive creative display, an in-depth display and a reality visit.

Detroit Institute of Art, Michigan, United States was an example of the use of digital technology towards display materials known as the 'Lumin AR Tour' which was introduced in 2017. This 'Lumin AR Tour' is a hand device utilized in buildings that provide information and assistance in the scanning of X-rays to get exposure to objects such as objects of mummies. The Cleveland Museum of Art, United States also uses the ArtLens Studio Play that exposes as interactive platform to the community. The studio is in the gallery that offers on-screen activities that require physical body movement. ArtLens Studio Play also offers virtual drawings, collages, static devices and easy access using mobile devices in researching and learning, a front camera with the ability to edit with artistic involvement and virtual pottery. The National Museum of Singapore performs a deep (immersive) exhibition. It is the concept of deep exhibitions through the use of large screens in the galleries featuring animation and visual as well as using the environment of digital technology, while the mobile application is also enhanced as a digital aid tool to obtain information on an exhibition object. Lastly, there was also a visit in the form of reality identified by Google in the form of applications that offer a digital experience on art and culture. This application requires the museum visitor to register and the museum space will be shown and this digital experience can be experienced anywhere without boundaries (Hillier, 2018). Kelly (2007) stated that the interactive approach applied in museum exhibitions leads to the development of learning experience by fulfilling the needs of visitors. A museum needs to move more holistically by bringing experience to its stakeholders. $70 \%$ of the museums depend on the number of attendees to remain relevant in the future. 
Azaman (2019) said that the museum of the world has used digital technology to organize exhibitions such as the National Museum of Singapore that display its European architecture facade's since 2017. Some museum institutions also focuses on online digital platforms through the Google Arts and Culture application. The application carries a virtual experience for a visitor in the museum exploration without being present in the museum. This application can be explored through the website (https://artsandculture.google.com) only. Through the Google Arts Culture application, visitors are served through an extensive digital technology, visitors able to explore unlimited online museums (Google arts \& culture, n.d.).

\section{Cultural Tourism of Museums Worldwide}

Gilmore and Rentschler (2002) said, museums today should focus on reaching larger audiences. This relationship provides a relationship which is called 'Museum-Audience' interaction. The change in the role of the museum by the director and the administration of the museum is to make changes to gain more involvement from the visitors. The trend of today's research has perceived the museum from the view of a holistic perspective, which covers the development of the museum to the community through digital technology, economy, environment and politics.

Cultural tourism is a global factor in the economic growth of the country. Statistics show that cultural heritage and tourism are developing mainly in The Organisation for Economic Co-operation and Development (OECD) and The Asia-Pacific Economic Cooperation (APEC). The global value of more than 1 billion dollars for the OECD countries and 327 million dollars for the APEC countries on cultural and heritage tourism contributes directly to 75 million available jobs (Childs, 2020).

Khairul Nishak binti Harun (Personal Communication, February 20, 2020), stated;

"I agree that museums are a tourist resource, since most museums are based on the culture of the local community. The establishment of the museum provides a holistic approach to the local community in terms of income and economy".

\section{Online Learning in Museums Worldwide}

From the perspective of a museum, the delivery of non-formal knowledge is provided to the individual and also society. This allows the museum to convey information to the users closely through collections in museums or by organizing an exhibition. The process of delivering information is more easily adapted than reading. This is because experiences can influence human thinking by remembering a state of culture, identity and civilization (Yusof, 2013). At the same time, museum exhibitions are classified as a semiology of communication. A semiology of communication is a scientific response that involves the analysis of artifacts, objects, symbols, pictures, and others. The 'semiology of communication' is a set of communications that analyses a subject and produces a message that wants the results to be conveyed (Hooper-Greenhill, 2012). The museum also offers visitors a museum learning experience. Learning about the museum is a substitution that gives the meaning of the museum experience. This is because the learning in the museum is different from formal learning. The museum's experience can be discovered based on personal interaction, social and physical interaction (Falk \& Dierking, 2000). 
Khairul Nishak binti Harun (Personal Communication, February 20, 2020), states;

"The digital or traditional exhibitions is a process of the exhibition, but the object of the exhibition shows elements of communication with past experience for the tourist."

In a modern context, a museum is important for the delivery of information processes and provides education to children and also to society generally towards the developments that positively occur around them. This approach can help them to understand and appreciate the history and should be proud of the efforts and achievements that have been cultivated by the previous generation. However, the understanding of educators and educational institutions towards the historical subject is important as it is seen as a role in contributing to greater experience in education. This is because each student experience encounter is different according to teaching and learning (Mohd Yusof \& Mohd Yusoff, n.d.). At the same time, a museum is not also a place for field trips, filling or relaxing time, but also contributes to the current educational method. Museums and educational institutions are closely related to achieving success in the scope of subjects taught by schools or educational institutions in a country. In Western countries, a museum act as a supporter of achieving national education goals (Hein, 1998). In Britain, a museum considered an educational institute that has been introduced since 1989. The museum practitioner collaborated with the government on the content of the curriculum (Mohd Yusof \& Mohd Yusoff, n.d.).

The institution of the museum is also known to reflect the point of the past. Khairul Nishak binti Harun (Personal Communication, 2020) stated;

"I believe that museums through exhibitions are a reflection of the past.

A museum is a knowledge resource".

\section{Conclusion}

In conclusion, this study confirms that a museum is now connected with three aspects that associates with digital aspects, aspects of online learning and aspects of cultural tourism towards the community and tourists. A digital narrative approach is considered an element of entertainment and a new approach to the dissemination of knowledge by the museums. Although the development of the digital field is constantly growing, it remains low in the adaptation applied to museums. It is because the adaptation of digital technology is one aspect to stimulate the museum-based economy to be more interactive and also as a medium of knowledge development.

A new dimension of the development of digital technology for museum exhibitions should be expanded to attract visitors to museum business, as well as a new approach to exhibitions in the museum with the development of digital technology based on the needs of the community today. The implementation of digital technology in the museum is not only more active, it also gives a continuation of the paradigm to the socio-economic community through cultural tourism. 
INTERNATIONAL JOURNAL OF ACADEMIC RESEARCH IN BUSINESS AND SOCIAL SCIENCES

Vol. 10, No. 6, June, 2020, E-ISSN: 2222-6990 @ 2020 HRMARS

This is because a museum is one of the leading mobilizers to the cultural tourism of a country. This is significant due to the culture and cultural objects such as the craft, custom, and culture play a medium income role for the community through the tourism industry. Finally, this study shows that a museum is not established as a center of depository data but also related to education, capability, and communication. This is because the significance of a museum can be evaluated by the presence of visitors.

\section{Acknowledgement}

This paper is supported by the Faculty of Film, Theatre and Animation and Geran GIP (600-IRMI 5/3/GIP (011/2019)) granted by Universiti Teknologi MARA (UiTM), Malaysia. 
INTERNATIONAL JOURNAL OF ACADEMIC RESEARCH IN BUSINESS AND SOCIAL SCIENCES

Vol. 10, No. 6, June, 2020, E-ISSN: 2222-6990 @ 2020 HRMARS

\section{References}

Awang, I. (2001). Kaedah penyelidikan suatu sorotan. Malaysia: Intel Multimedia and Publication.

Azaman, A. M. (2019). Enam Muzium Digital Lain Pendekatan Hampir Serupa dan Tersendiri. Sinar Harian. Retrieved March 2, 2020, from

https://www.sinarharian.com.my/article/39768/LIFESTYLE/Trend\%20/Enam-muzium-digitallain-pendekatan-hampir-serupa-dan-tersendiri.

Birtley, Margaret. (2002). A new definition of 'Museum', Insite: Museums Australia Inc (Victoria) newsletter, no. June-July, pp. 5-6.

Brown, M. (2020). Smartify Makes All Museum Audio Tours Free for Rest of 2020. The Guardian. Retrieved from https://www.theguardian.com/culture/2020/mar/26/smartify-makes-allmuseum-audio-tours-free-for-rest-of-2020.

Childs, C. (2020). How Culture and Heritage Tourism Boosts More Than A Visitor Economy. Retrieved March 2, 2020, from https://www.mytravelresearch.com/culture-and-heritage-tourismboosts-visitor-economy/.

Corsano, E. (2020). FIU Museums Engage Arts and Culture Lovers Working, Learning at Home. Retrieved March 2, 2020, from https://news.fiu.edu/2020/frost-art-museum,-the-wolfsonianfiu-and-jewish-museum-of-florida-engage-arts-and-culture-lovers-working-and-learning-athome.

Falk, J. H., \& Dierking, L. D. (2000). Learning from Museums: Visitors Experiences and the Making of Meaning. California, United States of America: AltaMira Press.

Gilmore, A., \& Rentschler, R. (2002). Change in Museum Management: A Custodial or Marketing Emphasis? Journal of Management Development, 21(10), 745-760. doi:10.1108/02621710210448020.

Google arts \& culture. (n.d.). Retrieved March 2, 2020, from https://culturalinstitute.google.com/. Hein, G. E. (1998). Learning in the museum. London, England: Routledge.

Hendrajit (2019). Menghadapi Era Digital 4.0, Museum Harus Bersinergi Dengan Pariwisata. Retrieved March 2, 2020, from https://theglobal-review.com/menghadapi-era-digital-4-0-museumharus-bersinergi-dengan-pariwisata/.

Hillier, L. (2018). How museums are using immersive digital experiences (pre- and post-pandemic). Retrieved from https://econsultancy.com/how-museums-are-using-immersive-digitalexperiences/.

Hooper-Greenhill, E. (2012). Museums and their visitors. London, England: Routledge.

Kelly, L. (2007). Visitors and learners: Adult Museum Visitors' Learning Identities. Retrieved from https://media.australian.museum/media/dd/Uploads/Documents/9316/Paper\%20CECA\%202 007.58e735c.pdf.

Kozinets, R., Gretzel, U., \& Dinhopl, A. (2017). Self in Art/Self As Art: Museum Selfies As Identity Work. Frontier in Psychology, 8(731), 1-12. doi:https://doi.org/10.3389/fpsyg.2017.00731

Mohd Yusof, M. A., \& Mohd Yusoff, M. F. S. (n.d.). Muzium Sebagai Institusi Pendidikan Tidak Formal Dalam Pengajaran \& Pembelajaran Subjek Sejarah. Retrieved from http://www.jmm.gov.my/files/Muzium\%20Sebagai\%20Institusi\%20Pendidikan\%20Tidak\%20F ormal\%20Dalam\%20Pengajaran\%20\%26.pdf

Münster, S., Hegel, W., \& Kröber, C. (2017). A classification model for digital reconstruction in context of humanities research. Lecture presented at Lecture in Computer Science in Technische Universität Dresden, Dresden. Retrieved from 
INTERNATIONAL JOURNAL OF ACADEMIC RESEARCH IN BUSINESS AND SOCIAL SCIENCES

Vol. 10, No. 6, June, 2020, E-ISSN: 2222-6990 @ 2020 HRMARS

https://www.researchgate.net/publication/309385677_A_classification_model_for_digital_re construction_in_context_of_humanities_research.

Pasikowska-Schnass, M. (2018). Cultural heritage in EU policies. Retrieved March 2, 2020, from https://www.europarl.europa.eu/RegData/etudes/BRIE/2018/621876/EPRS_BRI\%282018\%29 621876_EN.pdf.

Pedersoli Jr, J. L., Antomarchi, C., Michalski, S., Malapitan, C., Foulquié, M., \& Irqsosy, M. (Eds.). (2016). A Guide to Risk Management of Cultural Heritage (pp. 1-118) (Canada, Government of Canada, Canadian Conservation Institute). Canada, Canada: Government of Canada.

Perera, K. (2013). International Conference on Asian Art, Culture and Heritage. In The Role of Museums in Cultural and Heritage Tourism for Sustainable Economy in Developing Countries (pp. 1-7). Kelaniya, Sri Lanka: University of Kelaniya. Retrieved March 2, 2020, from https://www.researchgate.net/publication/237099471_The_Role_of_Museums_in_Cultural_ and_Heritage_Tourism_for_Sustainable_Economy_in_Developing_Countries.

Sternau, S. A. (1999). Museums: Masterpieces of architecture. New York, United States of America: Todtri.

Stow, A. (2011). Digitisation of Museum Collections. A Worthwhile Effort?. Retrieved 2020, from https://gupea.ub.gu.se/bitstream/2077/26817/1/gupea_2077_26817_1.pdf.

Sub-projects (2020). The project museum4punkt0. Retrieved March 2, 2020, from https://www.museum4punkt0.de /en/sub-projects/.

Universiti Malaysia Pahang (2020). Revolusi Industri 4.0. Retrieved March 1, 2020, from https://bendahari.ump.edu.my/index.php/en/info-kewangan1/530-revolusi-industri-4-0.

Yatim, O. (2005). Syarahan Perdana Pembudayaan Muzium, Pelestarian Warisan dan Pembinaan Bangsa. Wilayah Persekutuan Kuala Lumpur: Penerbit Universiti Malaya.

Yusof, A. R. (2013). Dunia digital: Pengajian Alam Melayu. Kuala Lumpur, Wilayah Persekutuan Kuala Lumpur: Penerbit Universiti Malaya. 